Brandeis | иввая

brandeis.edu/j-caste
CASTE: A Global Journal on Social Exclusion

Vol. 2 No. 2 pp. 34 I-358

October-November 2021

ISSN 2639-4928

https://doi.org/10.26812/caste.v2i2.218

\title{
On the Margins of Healthcare: Role of Social Capital in Health of Migrants in India
}

\author{
Shriyuta Abhishek' and Nanda Kishore Kannuri
}

\begin{abstract}
Social capital is a widely studied concept in sociology, philosophy and development economics since the late nineteenth century. In India, the various dogmas of the theory of social capital have not been studied to their potential, especially in the domain of public health. This study was conducted to determine healthcare access among migrants and their social capital, in order to explore the association between social capital and healthcare access. A mixed-method approach was adopted for the study. A survey $(n=6 \mathrm{I})$ was conducted in a residential area in Bilaspur district of Chhattisgarh state, using Shortened Adapted Social Capital Assessment Tool (SASCAT). The qualitative component of the study will be published separately. It was found that 78.6 percent of migrants have a 'low' social capital and 21.3 percent have a 'high' social capital. Fischer's exact test showed that there is no significant association between the economic status and social capital of individuals $(p=0.06)$. The research study concluded that there is a linkage between social capital and healthcare access. High social capital resulted in better healthcare access, especially among vulnerable groups (women, disabled and elderly people). The findings of the study helped in charting out the pathways of healthcare access within the framework of Bordieu's theory of social capital. It can be said that the concept of social capital has remained unexplored by academia and policymakers alike. In order to improve the healthcare access of migrants, health systems must delve into the complex nuances around tenets of social capital in healthcare.
\end{abstract}

\section{Keywords}

Social Exclusion, Caste, Health system, Health equity, Universal Health Coverage, Urban health

'BDS, MPH, Infosys Fellow,

Society for Education, Action and Research in Community Health (SEARCH), Maharashtra

E-mail: shriyuta06@gmail.com

${ }^{2}$ Ph.D., Additional Professor,

Social and Behavioural Sciences, Indian Institute of Public Health, Hyderabad

\section{*Corresponding author}

Nanda Kishore Kannuri

E-mail:nandu.k@iiphh.org

(C) 202I Shriyuta Abhishek, et al. This is an open access article distributed under the terms of the Creative Commons Attribution License, which permits unrestricted use, distribution, and reproduction in any medium, provided the original author(s) and source are credited. 


\section{Literature Review}

Migration is an important demographic event that receives significant attention in the field of public health. According to the Census of India (2011), a movement will be termed as 'migration' if it involves a change of residence from one village/town to another village /town. In the latest Census of 2011, two different types of migration were recorded. These were based on Place of Birth and Place of the Last Residence. In case of internal migration, there are three major components that contribute to the growth of urban population in India, namely, natural population growth, ruralurban migration, and reclassification of rural areas as urban during the course of time. Census 2011 showed that the growth of the rural-urban population has increased. It further reported that in the growth of the total urban population of the country, the contribution of rural-to-urban migration is higher than urban-to-urban (Census of India, 2011) (Lone \& Rather, 2012). People migrate for work/employment, business, education, marriage, etc. There are numerous types of internal migration that take place in India, including permanent, semi-permanent and circular migration. Internal migrants (those engaged in semi-permanent and circular migration) that move for employment work mostly end up working in precarious conditions (Abbas \& Varma, 2014). Women make up 70.7 percent of internal migrants as per Census 2001, and 80 percent of total internal migrants percent as per NSSO (2007-08). Marriage emerges as the most common reason for migration such that 91.3 percent of women in rural areas and 60.8 percent of women in urban areas stated that they migrated due to marriage. Notably, there are variations among caste groups when it comes to patterns of migration, such that circular migration is commonly seen among the Scheduled Castes (SCs), Scheduled Tribes (STs) and Other Backward Classes (OBCs) which has been associated with poor access to resources in host areas (Faetanini et al. 2013). In urban areas, internal migrants lack social security to sustain themselves and their families. Health and healthcare, which can be seen as an extension of social security, also remains a challenge. From a healthcare point of view, migration is not an inherently precarious phenomenon but working class migrants are put in such situations due to lack of a strong public healthcare system. Socio-economic issues faced by internal migrants aren't merely a result of policy failures, it rather reflects upon the structural inequalities embedded in our system. In 2008, World Health Organization released the Commission for Social Determinants of Health report wherein, Social Determinants of Health (SDH) were defined as 'the conditions in which people are born, grow, live, work, and age including the health system'. It can be said that migration governs the access and utilization of healthcare services by people. Migration along with other social determinants of health, i.e. housing conditions, modes of livelihood, gender, religion, caste, etc., influences healthcare access for people (Dodd et al. 2017).

Chhattisgarh is one of the Empowered Action Group (EAG) states with a fifth schedule status. The state has witnessed intra-state and inter-state migration since its bifurcation from Madhya Pradesh in 2000. The migration rate of Chhattisgarh is higher than the migration rate of India (Lone \& Rather, 2012). According to Census 2011, about 16 percent of intra-state migrants in India belong to the Scheduled Caste (SC) and 8 percent to the Scheduled Tribes (ST). Similarly, in Chhattisgarh, an 
undisputed link between migration and caste can be observed. The state is largely inhabited by Scheduled Tribes including the Gond, Baiga, Korba, Bison Horn Maria, Halba, among others. Scheduled Caste (SC) and Scheduled Tribes (ST) comprise 12.8 percent and 20.8 percent respectively. The percentage of Other Backward Castes (OBCs) is expected to be high but the exact figures remain unknown. In Chhattisgarh, ST population living in rural areas has reduced over time (37.6 percent in 2001, 36.8 in 2011), which is in contrast with data of states like Odisha, Jharkhand and Bihar where the percentage of ST population living in rural area has increased from 2001 to 2011 (Office of Census Commissioner, 2011). Caste also plays a critical role in shaping the labourers market, such that upper caste and upper class migrant workers end up in high-paying jobs owing to the historical advantage they enjoy as against their $\mathrm{SC} /$ $\mathrm{ST} / \mathrm{OBC}$ counterparts. Most migrant workers (inter-state and intra-state) from $\mathrm{SC} /$ $\mathrm{ST} / \mathrm{OBC}$ communities in Chhattisgarh are engaged in the informal sector ("A Brief Profile of Raipur City', 2000). Our study was carried out in Bilaspur district situated in the north-east region of Chhattisgarh. Bilaspur is the headquarters of South Eastern Coalfields Limited (SECL), a subsidiary of Public Sector Unit, Coal India Limited (CIL). It lies on the bauxite, limestone belt of Chhattisgarh. Bilaspur has a flourishing fertilizer and power generation industry which employs workers (migrants and nonmigrants) in large numbers ('The Movement and Creation of Chhattisgarh', 2000). Despite observing labourers migration for years, successive governments have failed to provide district-wise (and state level) data on human development indices including health status and healthcare access of migrants in the state. One way to understand the healthcare challenges faced by migrants in the discourse on Social Determinants of Health, is by exploring the role of social capital in healthcare. Social capital is an evolving concept that has a strong bearing on the health of the subaltern population. This study was conducted in Bilaspur district of Chhattisgarh state in order to assess the healthcare access of migrants living there. The aim of the study was to further understand the role of social capital in shaping the healthcare access of these migrants.

In this study, we adopted the Commission for Social Determinants of Health framework (2007) to assess the healthcare access of migrant communities. It is one of the latest and the most comprehensive frameworks developed by the World Health Organization (World Health Organization, 2018). In order to map the role of social capital in access to healthcare, Bourdieu's theory of social capital (1986) was also used. Bourdieu, in his theory of social capital, explains how long-term efforts and sociability of a group is a prerequisite to the acquisition of collective social capital, which is of utmost relevance to the migrant groups owing to the socio-political factors affecting their lives. Further, gender, caste, and class determine individual holding of social capital amongst the migrant groups. In the Indian subcontinent, the extent of social capital accrued by people over the period of their lives or at various stages of their lives, depends upon their caste location (Bourdieu, 1986). For the purpose of this study, we built upon Bourdieu's understanding of social capital and aligned it with the Comprehensive Social Determinants of Health framework. In order to convert social capital into a quantifiable parameter, it is broken down into two components, i.e. cognitive social capital (trust, social cohesion) and structural social capital (citizenship, social participation). This was done in line with the Shortened Adapted Social Capital Assessment Tool (SASCAT) used in the study (Kaplan et al. 2016). 


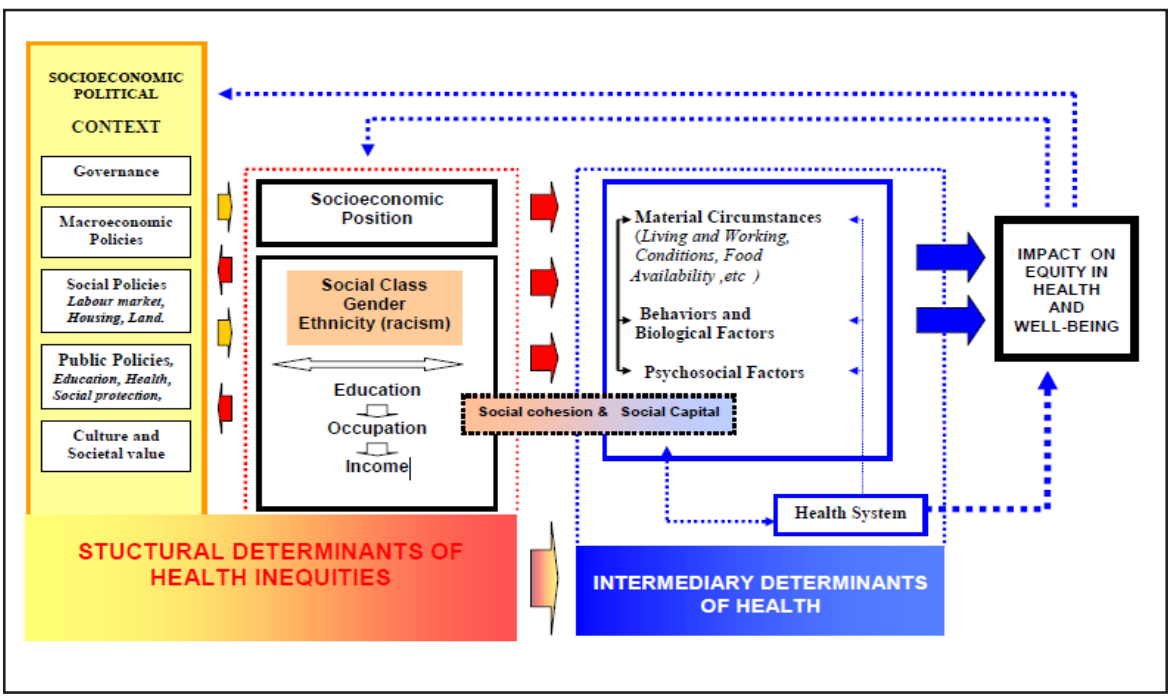

Figure I: Comprehensive Social Determinants of Health framework (World Health Organization, 2018)

\section{Methods}

A mixed-method approach was used to conduct the research. Commission for Social Determinants of Health framework and Bourdieu's social capital theory (1986) was used for the conceptualization of the study. The purpose was to examine healthcare access by studying the structural and intermediary determinants to health, with social capital as a cross-cutting determinant (World Health Organization, 2018). The idea was to navigate the pathways of marginalization vis-à-vis social location (migrant status, occupation, gender, caste, etc.) in line with Bourdieu's social capital theory (1986). Bourdieu's theory provided a unique understanding to social determinants of health; a shift from traditional ways in which an individual's social location is determined. His theory was adopted for the study because Bourdieu argues that inequality in material terms is considered in policy planning but the inherent factors that lead to inequality are often masked. He also explains the dynamic relationship between social capital and other forms of capital (economic and cultural capital) (Bourdieu, 1986). Further, social capital was studied to map healthcare access by determining complex ways in which social capital influences a community's health and well-being.

\section{Study settings}

The study was conducted in Atal Awaas, a residential project built under Integrated Housing and Slum Development Program (IHSDP) in various parts of Bilaspur including in the city council of Sakri, Bilaspur, Chhattisgarh. Currently, Atal Awaas has been allocated to families that previously lived in slum areas of Bilaspur. It was chosen for our study as it houses a heterogeneous group of migrants, who have migrated from within the state and from other states in India. 


\section{Sampling, sample size and data collection}

The study broadly comprises two population groups, migrant individuals and local stakeholders. Local stakeholders are a people who are responsible for governance/ healthcare governance, and frontline workers like mitanins (ASHAs) in the area. There are a total of 650 households that live in 26 blocks (each residential building is delineated as a block) of Atal Awaas. Households in the residential blocks were considered the primary unit of sampling. A sampling frame of all the households in Atal Awaas was not available with the Bilaspur Municipal Corporation at the time of the study. Hence, for the survey, convenience sampling was used to select the blocks (block A, B, C). Out of the sampling frame of 72 households with enumeration of all the adult members of the household, 61 individuals from 61 households, i.e. one member/ individual from each household was recruited. Simple random sampling method was used to select 61 households. Individuals were selected based on their availability at the time of the survey. A sample size was calculated using Open Epi Version 3 with the formula $n=[\mathrm{DEFF} * \mathrm{~Np}(1-\mathrm{p})] /\left[\left(\mathrm{d}^{2} / \mathrm{Z}^{2}{ }_{1-\alpha / 2} *(\mathrm{~N}-1)+\mathrm{p}^{*}(1-\mathrm{p})\right]\right.$; population $(\mathrm{N})=2500$, anticipated frequency of 'low' social capital (in percentage) $=80$ (based on previous studies) absolute precision $=10$. Purposive and quota sampling method was used in to recruit participants for focus group discussions and in-depth interviews. Shortened Adapted Social Capital Assessment Tool (SASCAT) is a validated questionnaire, first developed by the Young Lives project based on the World Bank Social Capital assessment tool (Kaplan et al., 2016). SASCAT has also been adapted to Indian settings. It has previously been used in Andhra Pradesh and Nagaland (Kaplan et al., 2016; Wilson \& Mccoy, 2006). SASCAT was translated to the local language, Hindi. The tool consists of 11 items with a maximum score of 11 (for each item) and the minimum score of 0 . Social capital has been categorized into two groups, 'high' and 'low' based on the cutoff used in previous studies done in India (Kaplan et al., 2016). 'Low' social capital is categorized by $0-4$, while $5-11$ is categorized as 'high' social capital. Semi-structured interviews, focus group discussion and indepth interview guides were also translated to the local language. Purposive sampling and quota sampling was carried out to recruit participants for in-depth interviews and focus group discussions in order to utilize the principle of maximum variation. Three respondents were included for each quota. For the focus group discussion, participants were recruited with the help of a community member. It was ensured that the group was representative of the heterogeneous study population in terms of age, gender, religion, caste and health conditions. Twelve members participated in the focus group discussion. In-depth interviews and focus group discussion were carried out in Hindi.

\section{Data analysis}

Quantitative data were cleaned and sorted in Excel 2010, analyzed in Stata 13.0 (Stata Corp, USA). Descriptive statistics were performed to report frequency and percentages. The relationship between key variables were studied by conducting statistical tests of association. Qualitative data was collected by means of in-depth interviews and focus group discussion. It was recorded, transcribed and later, translated from the local language, Hindi with the consent of the participants. Qualitative data is analyzed using 
thematic analysis method. Apriori codes have been developed based on research tools. Emerging codes were developed as the data was interrogated during the analysis.

Table I: Socio-demographic details of the participants

\begin{tabular}{|l|c|}
\hline \multicolumn{1}{|c|}{ Characteristic } & Frequency (\%) \\
\hline Total no. of participants $(\mathrm{n})$ & $61(100)$ \\
\hline Sex distribution & $14(22.9)$ \\
\hline Male & $47(77.0)$ \\
\hline Female & \\
\hline Caste distribution & $13(21.3)$ \\
\hline Scheduled Caste & $24(39.9)$ \\
\hline Scheduled Tribes & $18(29.5)$ \\
\hline Other Backward Caste & $6(9.8)$ \\
\hline Others & \\
\hline Employment status & $44(72.1)$ \\
\hline Employed & $17(27.8)$ \\
\hline Unemployed & \\
\hline
\end{tabular}

Table 2: Migration characteristics of the study population

\begin{tabular}{|c|c|c|}
\hline \multicolumn{2}{|c|}{ Migration characteristics } & Frequency (\%) \\
\hline \multicolumn{2}{|l|}{ By place of birth } & $57(93.4)$ \\
\hline \multicolumn{2}{|c|}{ By the last place of residence } & $53(86.8)$ \\
\hline \multicolumn{2}{|c|}{$\begin{array}{l}\text { Both by place of birth \& by the last place of } \\
\text { residence }\end{array}$} & $49(80.0)$ \\
\hline \multicolumn{2}{|l|}{ Exclusively by place of birth } & $8(13.1)$ \\
\hline \multicolumn{2}{|c|}{ Exclusively by last place of residence } & $4(6.5)$ \\
\hline Migration stream & & Frequency (\%) \\
\hline \multirow{2}{*}{ Sub-state level } & Rural to urban & $25(41.0)$ \\
\hline & Urban to Urban & $36(59.0)$ \\
\hline \multirow{2}{*}{ State-level } & Intra-state migration & $52(85.2)$ \\
\hline & Inter-state migration & II (18.0) \\
\hline Total participants (n) & & $61(100)$ \\
\hline
\end{tabular}

\section{Social capital}

Two forms of social capital have been reported, cognitive social capital and structural social capital. Overall, 48 participants (78.6 percent) reported 'low' social capital, i.e. their social capital score ranged between 0 to 4 . Thirteen participants ( 21.3 percent) reported a 'high' social capital, i.e. their social capital score ranged between 5 to 11 . Sixteen (26.2 percent) participants who were unemployed reported a 'low' social 
capital and one (1.6 percent) reported a 'high' social capital. Migrants belonging to the Gond/Koitur tribe had the lowest social capital 17 (27.9 percent) followed by Scheduled Castes at 12 (19.3 percent). We applied Fischer's exact test to assess the association between the employment status of participants and their social capital and it was reported to be statistically insignificant ( $p$ value $>0.05$ ).

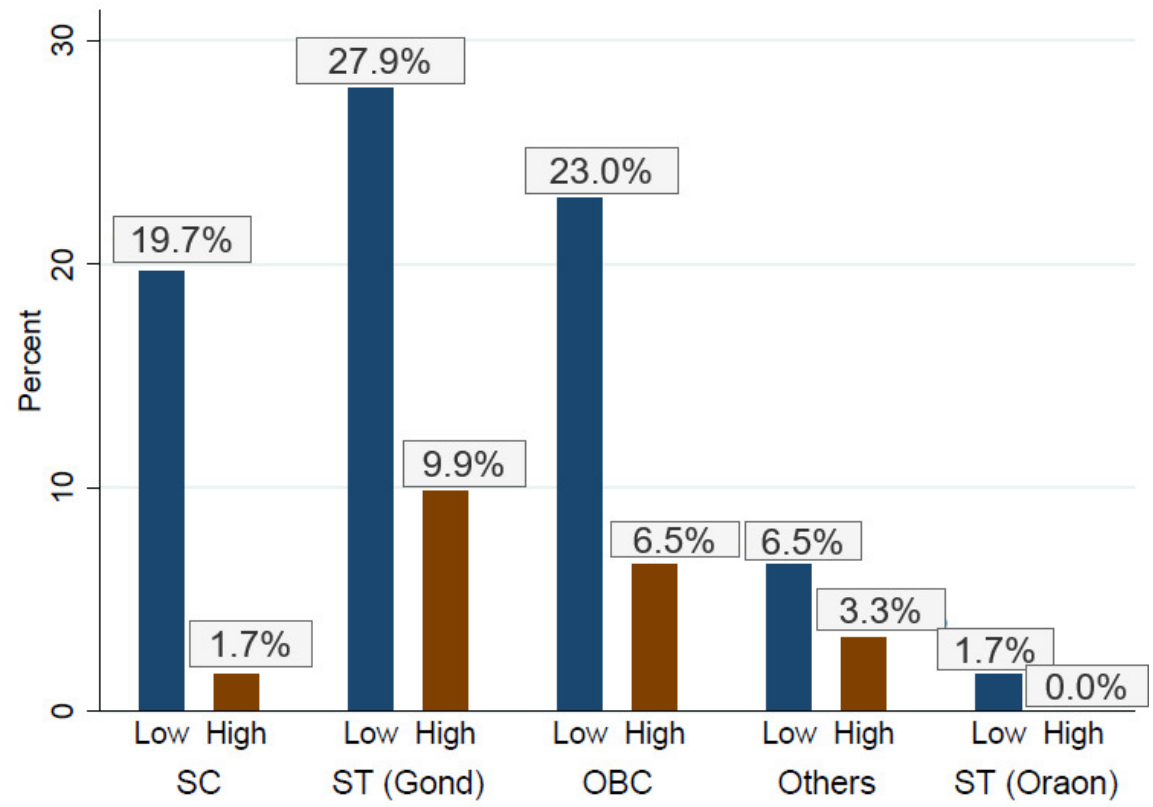

Figure 2: Distribution of social capital among the caste groups

Table 3: Distribution of social capital based on employment status

\begin{tabular}{|l|c|c|c|}
\hline \multirow{2}{*}{$\begin{array}{c}\text { Employment } \\
\text { status }\end{array}$} & \multicolumn{2}{|c|}{ Social capital } & \multirow{2}{*}{ Total } \\
\cline { 2 - 4 } & Low social capital & High social capital & \\
\hline Unemployed & $16(94.1)$ & $1(5.8)$ & $17(100.0)$ \\
\hline Employed & $32(72.7)$ & $12(27.2)$ & $44(100.0)$ \\
\hline Total & $48(78.6)$ & $13(21.3)$ & $6 I(100.0)$ \\
\hline
\end{tabular}

\section{Cognitive social capital}

Cognitive social capital was measured in the form of 'trust' and 'social cohesion' among the participants. Most people, 36 individuals (59 percent) reported that they trusted their neighbors but 54 people ( 88.5 percent) did not trust their local leaders and strangers 57 (93.4 percent) in the area. Twenty-five people (40.5 percent) reported that they do not trust their neighbours, 7 people (11.4 percent) trust the local leaders and 4 people ( 6.5 percent) trust strangers in their area. Social cohesion is the degree to which people have managed to assimilate into the community. Thirty-four people (55.7 percent) felt that those living in the community get along with each other, while 
27 persons (44.3 percent) said that people do not get along with each other. Thirty-nine people (64 percent) said that they feel like a part of the community, while 22 people (36 percent) did not experience a sense of belonging with the community.

\section{Structural social capital}

Structural social capital was measured in the form 'citizenship' and 'social participation'. Citizenship was measured by asking people whether or not they voted in the last elections of electoral and enquiring about the degree of involvement people had with the issues pertaining to the residential area (Atal Awaas). Thirty-nine people (63 percent) voted in the last local/general elections, while 22 persons (36 percent) did not vote in the last elections. Thirty-three people (54.1 percent) did engage in the process of finding a solution for an issue related to the residential area. A majority of persons, i.e. 50 people (81.9 percent) alone or collectively, did not report any issue to local authorities.

Social participation refers to the degree of involvement, social activeness displayed by the people living in the housing society. The presence or absence of this trait was determined by the support they received from groups and individuals. Fortyfive people (73.7 percent) were not a member of any group in the last twelve months (March 2018-February 2019). Only 16 participants (26.2 percent) reported to have been a part of at least one social/political/cultural group in the last twelve months. Out of which 10 (62.5 percent) received emotional/economic or other sort of support. 33 persons (54.1 percent) reported having received emotional/economic or another sort of support from individuals. People received support of various kinds of individual support, 26 people received support from their family members, 13 persons received support from their neighbors, 9 persons received support from their friends (who were not neighbors), 7 persons received support from their employers. All of those who received support from a group, received it from a single group. Figure 3 depicts the type of group participation among sixteen participants who reported to be a part of one group.

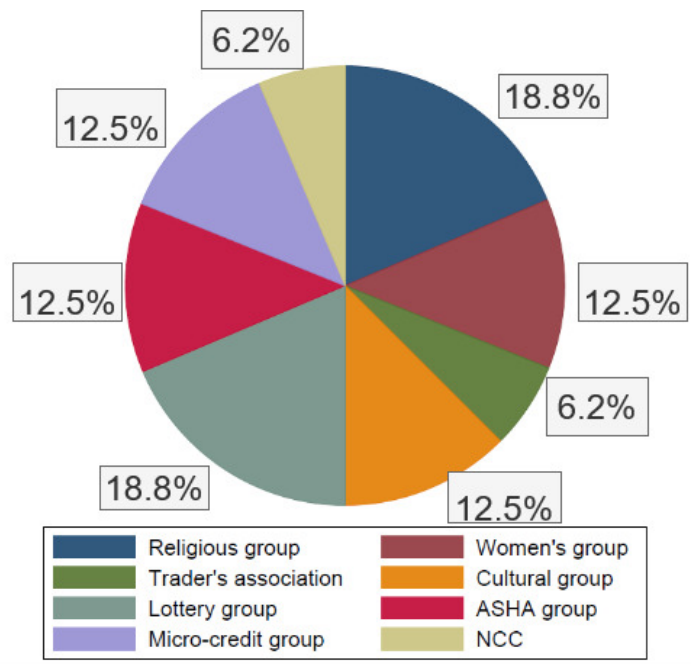

Figure 3:Type of group participation for people who were a part of a group. 
Forty-two persons $(68.8 \%$ percent $)$ owned an LPG stove, 40 persons (65.5\% percent) owned a bike and 19 persons (31.5\% percent) owned a TV. Fischer's exact test was conducted to determine the association of socioeconomic status with social capital. It was found that 9 people (100 percent) of people who did not own any durable good (TV, motorcycle) and LPG stove had a low social capital, 11 people (61.1 percent) of people who at least owned 1 durable good/LPG stove had a low social capital, 17 people ( 89.5 percent) people who owned at least 2 durable goods/LPG stove had a low social capital and 11 people (73.3 percent) people who owned all the two durable goods and an LPG stove had a low social capital. This difference was statistically insignificant $(\mathrm{p}=0.06)$.

\section{Healthcare access to the community}

In this sub-study, some important findings from the qualitative component of the larger study will be reported in order to corroborate it with the quantitative data. Qualitative findings suggest that migrants have limited healthcare access. Public health facilities include only a Sub-Center (SC) that is geographically accessible, however, there human resources (Auxillary Nurse Midwife) and diagnostic services are lacking in the sub-center. People living in Atal Awaas felt that it was difficult to travel to the Primary Healthcare Center (PHC) of Sakri. Moreover, there is a lack of availability of doctors in the PHC. We noted that the PHC is located beyond a radius of $5 \mathrm{~km}$. from Atal Awaas. People do not receive routine primary healthcare services including maternal and child health services (ante-natal care, immunization). Government-run secondary and tertiary care healthcare centers are inaccessible for most people. Home deliveries as against institutional deliveries are common in Atal Awaas as referrals to district hospital are made from the SC/PHC in most cases. Hence, women have no option but to deliver at home because of a shortage of transport facilities. There is no provision for emergency services for injury and trauma for people living in Atal Awaas in the nearby health centers and people have low awareness about the free ambulance services provided by the government, i.e. 102 Mahatari express and 108 ambulance services. In the absence of adequate public health facilities, the private sector has thrived in the area. In effect, there are inadequate affordable primary healthcare services for the residents of Atal Awaas. In our study, we found that those with better social capital had improved healthcare access (to private health services), especially among people who were active members of society, i.e. had better social participation. As a community, people experience a lack of political support in matters of welfare and health, which translates into a low cognitive social capital. 
Table 4: Quotes from in-depth interviews and Focus-Group Discussion

\begin{tabular}{|c|c|c|}
\hline $\begin{array}{l}\text { Role of social capital } \\
\text { in healthcare access }\end{array}$ & Quotes from IDIs and FGDs & Interpretation \\
\hline $\begin{array}{l}\text { Physical accessibility } \\
\text { of healthcare } \\
\text { services \& social } \\
\text { participation }\end{array}$ & $\begin{array}{l}\text { 'Whenever healthcare services are needed, } \\
\text { we look for transport facility. If we have any } \\
\text { friend, or neighbor who has [a] motorcycle } \\
\text { or even bicycle, we take help. It is expensive } \\
\text { to even take a private auto-rickshaw. Had } \\
\text { there been any transport facility, it would } \\
\text { have been better.' (26-year-old, female, FGD) }\end{array}$ & $\begin{array}{l}\text { People have to rely on their } \\
\text { friends, neighbors to seek } \\
\text { healthcare services. }\end{array}$ \\
\hline $\begin{array}{l}\text { Affordability, } \\
\text { physical accessibility } \\
\text { of healthcare } \\
\text { services, and social } \\
\text { cohesion. }\end{array}$ & $\begin{array}{l}\text { 'No work gets done without spending } \\
\text { money these days. If there was [a] hospital } \\
\text { nearby we would tell that we will pay you } \\
\text { tomorrow once we get some money (as } \\
\text { we used to do earlier when we lived in } \\
\text { the city). That's not possible since we have } \\
\text { relocated here.' ( } 58 \text {-year- old, female, FGD) }\end{array}$ & $\begin{array}{l}\text { Although quantitative } \\
\text { findings suggest that most } \\
\text { people experience a sense } \\
\text { of belonging with the place, } \\
\text { some residents lacked a } \\
\text { sense of belonging owing to } \\
\text { the lack of familiarity with the } \\
\text { surroundings. }\end{array}$ \\
\hline $\begin{array}{l}\text { Affordability, } \\
\text { physical accessibility } \\
\text { of healthcare } \\
\text { services and trust }\end{array}$ & $\begin{array}{l}\text { 'We go to CIMS hospital (tertiary care } \\
\text { public hospital) or district hospital; it is } \\
\text { mostly the two but only when we have } \\
\text { money otherwise it keeps hurting but it } \\
\text { only gets healed if you have money or } \\
\text { you manage to borrow money and get } \\
\text { treatment.' ( } 55 \text {-year-old, male, FGD) }\end{array}$ & $\begin{array}{l}\text { Trust plays an important } \\
\text { role when people have } \\
\text { to lend money to others } \\
\text { for treatment purposes. } \\
\text { People have to pay out-of- } \\
\text { pocket (Organisation for } \\
\text { Economic Co-operation } \\
\text { and Development [OECD] } \\
\text { defines out-of-pocket } \\
\text { payments as expenditures } \\
\text { borne directly by a patient } \\
\text { where insurance does not } \\
\text { cover the full cost of the } \\
\text { health good or service) } \\
\text { because of inadequate public } \\
\text { health facilities nearby. }\end{array}$ \\
\hline $\begin{array}{l}\text { Physical accessibility } \\
\text { of healthcare } \\
\text { services, trust and } \\
\text { citizenship }\end{array}$ & $\begin{array}{l}\text { 'We go to the Anganwadi Center in } \\
\text { Mangla Chowk (Bilaspur) as there is no } \\
\text { Anganwadi Center nearby. Earlier there } \\
\text { were two AWCs near our hut (in the slum } \\
\text { area). Once, the the husband of the Ward } \\
\text { Representative visited, I request him to do } \\
\text { something about it but he doesn't seem to } \\
\text { care.' ( } 58 \text {-year-old, female, FGD) } \\
\text { 'There's no one here. They only vaccinate } \\
\text { some children and go. We asked to start } \\
\text { an AWC here but they said it is less likely } \\
\text { to establish an AWC here.' ( } 26 \text {-year-old, } \\
\text { female, FGD) }\end{array}$ & $\begin{array}{l}\text { People with children younger } \\
\text { than } 6 \text { years old and pregnant } \\
\text { women were particularly } \\
\text { concerned that there was } \\
\text { no AWC nearby. They even } \\
\text { registered their concerns to } \\
\text { the local leader in whatever } \\
\text { limited interaction they had. }\end{array}$ \\
\hline $\begin{array}{l}\text { Appropriateness of } \\
\text { health services, trust } \\
\text { and citizenship }\end{array}$ & $\begin{array}{l}\text { 'Healthcare services are not satisfactory } \\
\text { (public and private health services). What } \\
\text { improvement can be done when there } \\
\text { aren't any services in the first place? I doubt } \\
\text { if anybody (local leaders) care.' (38-year-old, } \\
\text { male, FGD) }\end{array}$ & $\begin{array}{l}\text { Most people did not trust } \\
\text { their local leaders and did } \\
\text { not believe that would do } \\
\text { make any concrete changes } \\
\text { to improve the state of } \\
\text { healthcare services. }\end{array}$ \\
\hline
\end{tabular}




\begin{tabular}{|l|l|l|}
\hline $\begin{array}{l}\text { Access to health- } \\
\text { related information, } \\
\text { social cohesion and } \\
\text { citizenship }\end{array}$ & $\begin{array}{l}\text { 'Here, the thing is that mitanins (ASHA) } \\
\text { don't give us any information. There are } \\
\text { mitanins in our first block but they don't } \\
\text { give us any information.' (26-year-old, } \\
\text { female, FGD) }\end{array}$ & $\begin{array}{l}\text { Mitanins themselves were } \\
\text { not a part of the community } \\
\text { living in Atal Awaas and } \\
\text { people did not share a sense } \\
\text { of community with her. } \\
\text { Pregnant women said they } \\
\text { were never visited by the } \\
\text { mitanins. }\end{array}$ \\
\hline $\begin{array}{l}\text { Affordability } \\
\text { of healthcare } \\
\text { services and social } \\
\text { participation }\end{array}$ & $\begin{array}{l}\text { 'Our girl had fallen ill at midnight, we rushed } \\
\text { to a private hospital.The hospital had a } \\
\text { board which suggested that they accept } \\
\text { smartcard but they refused to accept it. We } \\
\text { had to give Rs. 3 lakh in cash at a private } \\
\text { hospital.Then, why have they (private } \\
\text { hospital) put up a board for smartcard } \\
\text { services when you aren't offering to use it?'? } \\
\text { (39-year-old, female, FGD) }\end{array}$ & $\begin{array}{l}\text { People who had better } \\
\text { social participation were } \\
\text { more likely to be aware of } \\
\text { or utilize state-funded health } \\
\text { insurance schemes like RSBY. } \\
\text { However, private healthcare } \\
\text { facilities empanelled under } \\
\text { RSBY would frequently deny } \\
\text { services. }\end{array}$ \\
\hline
\end{tabular}

\section{Discussion}

In our study we found that 78.6 percent people had a 'low' social capital, whereas only 21.3 percent had a 'high' social capital. In terms of trust, people did not trust their local political leaders but placed relatively high trust in their neighbors. Social cohesion among people remains relatively low due to varied social backgrounds, and individual challenges (gender-based or other circumstantial factors). Most people worked more than 10 hours to make ends meet, which explains why many have limited social participation. Social capital also varied among different caste groups. Most people living in Atal Awaas belonged to marginalized caste groups (SC, ST, and $\mathrm{OBC}$ ). A majority of migrants identified as a member of the Gond/Koitur tribe, which is the largest tribe in central India (Ministry of Tribal Affairs, 2014). Few upper caste people reside in Atal Awaas yet they have better social capital than their SC/ST/ OBC counterpart - which speaks volumes about caste dynamics and its role in migrant health. The OBC community fared better than their ST/SC counterparts in terms of social capital, economic capital and healthcare access. Also, those who seek better political leadership, experience a sense of indifference from local leaders (e.g. a ward representative who belonged to an upper caste group) due to existing caste/class based hierarchy. It is important to underline that the lack of political representation also leads to a deficit in social capital over time, in turn restricting their healthcare access. (Bourdieu, 1986). It can also be argued that caste-based identities are relational and not absolute in this regard. Hence, overrepresentation of upper caste people (relative to their caste location and their corresponding percentage in the population) is a result of underrepresentation of marginalized caste groups (Mosse, 2018). Healthcare access was found to be improved for people who have better cognitive and structural social capital especially when it comes to women (and children). Women could rely upon their neighbors or family in times of need, whereas men (even elderly men) had improved access to healthcare owing to their social participation, which has been previously shown in studies conducted in Peru, Vietnam and India (Garlick et al. 2006). The elderly and disabled persons with 'low' social capital (mainly structural 
social capital) had poor access to healthcare. Better social capital also meant better access to information related to healthcare. Women tend to discuss health issues with neighbors, family, and women who work with them, whereas the elderly had no such support. Elderly people also felt that the frontline workers do not cater to their needs due to their age and hence, they lacked trust in frontline workers when it comes to provisioning of primary healthcare services. The case was no different for disabled people. These patterns highlight an inextricable link between marginality and social capital which is in consonance with Bourdieu's theory (Bourdieu, 1986). Migration also threatens the sustainability of social networks, which is again rooted in the concept of social capital accrued in the form of 'caste' capital. Unlike economic capital, social capital increases with use and offers greater protection against unforeseen social and economic challenges, including health events (Alha, 2018).

Sociologists and political philosophers in the West have commented on role of social capital in governance and economy in post-modern societies. Coleman viewed social capital as a form of resource (Coleman, 1988). Whereas, Putnam proposed that social capital expresses the sociological essence of communal vitality. He breaks down social capital into three components, i.e. trust, social norms/obligations and social networks, specially voluntary associations (Siisiäinen, 2000). Bourdieu, however, emphasized the plurality of social fields, and engaged in defining the role of social, cultural and economic capital in an individual's position in various social fields (Bourdieu, 1986). The present study adopted Bourdieu's theory to understand the relationship between healthcare access and social capital among migrants as he emphasizes on the structural factors behind existing disparity in ownership of various forms of capital. Apart from social capital, Bourdieu also talks about cultural and economic capital. He suggests that cultural capital exists in three forms, in the 'embodied state' or the way in which culture gets arranged in our mind and embedded in our lives, in the 'objectified state', i.e. in the form of cultural goods like books, pictures, etc., and in the 'institutionalized state', i.e. when cultural capital gains institutional recognition. Based on the findings of the qualitative component of the study, we found that the migrants living in Atal Awaas lacked cultural capital in its institutionalized state. Hence, they haven't received institutional recognition by the health system. Bourdieu contends that each form of capital can be converted into another form of capital under certain circumstances. According to Bourdieu, 'convertibility of the different types of capital is the basis of the strategies aimed at ensuring the reproduction of capital'. However, he puts economic capital at the center of his argument, by claiming that economic capital is at the root of each type of capital. We argue that economic capital may not necessarily be at the heart of all capitals as evident from our findings. Proxy markers of economic capital, i.e. owning a house, mobile phones or two-wheelers were not found to improve healthcare access per se. In the context of migration, social capital accrued through caste-based networks can be highly exclusionary benefitting only the dominant section (upper-caste migrants). Caste barriers can prevent people from acquiring long-term economic as well as cultural capital as the process relies on identity-based networks. These networks are unequal in their origin itself. Hence, it cannot possibly promote economic and cultural growth for those on the lower rung of the social hierarchy. 


\section{Social capital and healthcare access}

European experience suggests that in theory, the health benefits of social capital are received via three primary pathways. First, social capital helps in diffusion of information and hence, improves health/healthcare access. Second, social capital if accessed, is said to promote political organization, which helps in gaining access to healthcare resources. And third, social capital helps in individual and collective networking, which in turn result in better psychosocial support. Nordic countries like Norway, Finland and Sweden reported higher degrees of trust (a component of social capital) which was found to be correlated with better self-reported health status (Rocco \& Suhrcke, 2012). In India, the idea of social capital has received great attention from experts in the development sector but it has not been incorporated into health policy research. In terms of health and well-being of population, social capital has been associated with improved quality of life, wherein the social capital comes from local solidarity and social communication (Hans, 2014). A study carried out in Nagaland shows the relationship between social capital (structural and cognitive social capital) and utilization of health services in Nagaland. The study indicated that 'trust' within the community is an important factor to overcome barriers to access to healthcare. Social participation was associated with the utilisation of public health services over private services (Kaplan et al., 2016). Some studies could not decipher the complex relationship between social capital and health status of individuals but they certainly show that there is a lot more to unravel (Garlick et al., 2006).

Researchers have proposed that equity in healthcare can be measured by assessing parameters like accessibility, availability, appropriateness, and affordability of healthcare services (Gulliford et al., 2002). The ultimate aim is to reckon whether the health system is designed to fulfill the needs of socially disadvantaged groups or remains skewed towards the privileged groups. In 2011, a High-Level Expert Group constituted by the Planning Commission of India, submitted a report pertaining to Universal Health Coverage for India by 2022. The report tackles the aforementioned issues of inequity on various fronts including health infrastructure, human resources in health, community participation and health financing, etc. It clarifies that the idea of universality is mainly aimed at including remote and migrant communities and/ or communities that have been historically disadvantaged (Planning Commission of India, 2011).

World Health Organization (WHO) has been promoting Universal Health Coverage (UHC) with Declaration of Astana to being endorsed to focus on primary healthcare by centering marginalized communities (Jasarevic, 2019). If India as a nation intends to provide Universal Health Coverage to its citizens, there is an increasing need to understand the importance of the concept of social capital in the discourse on equity in healthcare. WHO promotes publicly funded health insurance as one of the pathways to achieve equitable service coverage under UHC (Dye et al., 2013). On the contrary we found that insurance remains an ineffective method to improve better healthcare coverage as only in line with the current evidence from Chhattisgarh. A study conducted in the slum areas of the capital of Chhattisgarh indicated that 43 percent of people living in the slums were not enrolled under state-funded healthcare insurance called Mukhyamantri Swasthya Bima Yojana. It has been established that insurance enrollment is rarely universal (Nandi et al., 2018) (Nandi et al., 2016). 
In South Asia, a prime way in which inequity manifests itself is in the form of caste. Caste, as a social system with economic and political bearings, is responsible for individual and structural discrimination against the marginalized caste groups. SC/ST and $\mathrm{OBC}$ communities comprise a majority of the population in Chhattisgarh compared to the percentage of upper caste living in the state (Ministry of Tribal Affairs, 2014). However, these communities have always had to assert their social, economic and political rights through various means in order to challenge the dominance of the ruling class. From the Bastar revolt of 1910 to the anti-caste movements in the nineteenth century, Chhattisgarh witnessed some prominent anti-colonial, anti-capitalist, anticaste and working class uprisings. In the early twentieth century, there was a boost in metal industry in Madhya Pradesh (now Chhattisgarh). There was a gradual shift from an agrarian economy to an industrial economy. This was followed by a strong wave of trade union movement under national and provincial trade unions in Chhattisgarh. Apart from the struggle for regularization of contract labourers, anti-mechanization and anti-departmentalization of workers, mine workers fought for better wages, health and safety of workers (including sanitation workers), allowances for housing repair, etc. Organizations like Chhattisgarh Mines Shramik Sangh (CMSS) had over 30,000 workers affiliated to it, which extended up to Hirri mines in Bilaspur district. CMSS could provide medical facilities by setting up a hospital for contract labourers working in Dalli-Rajhara, peasants living in nearby villages. Around the 1990s, the identity of Chhattisgarhi people was taking final shape after years of social, cultural and political developments although the idea of statehood was promoted as early as the 1950s. Multiple factors were responsible for the bifurcation of Madhya Pradesh into Chhattisgarh. One of the key links between the trade union movement and struggle for statehood was the fact that cultural suppression of Chhattisgarhi people was further leading to exploitation of workers. The widespread need to promote regional consciousness provided the political thrust for the formation of state. However, unlike its neighboring states (e.g. Jharkhand), Chhattisgarh did not see any strong political mobilization or an organized statehood movement. (Ish, 2017; "Necessities and Challenges of Reservation in Chhattisgarh," 1999; Tillin, 2014)

It is imperative to understand the challenges to healthcare access faced by migrants within the broader socio-political and cultural history of the state of Chhattisgarh. Hence, we have mapped the Commission for Social Determinants in Health framework to provide a better understanding of the multidimensional concept of health equity, and its significance with respect to healthcare access and social capital of migrants. The framework illustrates the role of structural and intermediary determinants of health on health equity. In our study, we discovered that structural determinants like the socialpolitical context that the community lives in, namely, quality of governance, economic and social policies and implementation of public policies, is of great importance in improving healthcare access for people. It further showed that individual/collective socio-economic position (age, gender, caste/class, migration, and disability) and material circumstances, psychosocial, biological factors shape the way people approach and get approached by the health system of Chhattisgarh. For example, among the migrants, Christian women from a tribal community, disabled men did not receive appropriate health services in public hospitals, whereas able-bodied men had better physical access to health facilities. An elderly man who identified as a follower of Saint Kabir, worked as an activist, had better healthcare access owing to his social capital, whereas an elderly woman with a blinding condition of cataract, lacked familial 
support and could not access health services. This indicates that social capital crosscuts across intermediary determinants of health. The effect of caste capital (in the form of social capital) is not confined to location (rural or urban). It takes shape by means of the dynamic inter-play between the intermediary (material circumstances, living conditions) and structural determinants of health (social structure, public policies). There is no way by which these networks can be transferred. In fact, unlike economic capital, social capital - increases with use and gets passed on to generations as a result of caste-based endogamy (Alha, 2018; Mosse, 2018). Eventually, it dictates individual/collective access to healthcare, thereby, perpetuating inequity in health outcomes. On an individual level, inequitable health outcome can manifest intragenerationally, whereas on a community level, it can have inter-generational consequences. Inequitable distribution of health outcome leads to skewed healthcare access and vice versa (World Health Organisation European Region, 2015). Within the intermediary determinants we have included 'social cohesion' as a component of social capital rather than viewing is as a separate entity. We have also emphasized the process of 'access to healthcare' prior to entry into the health system.

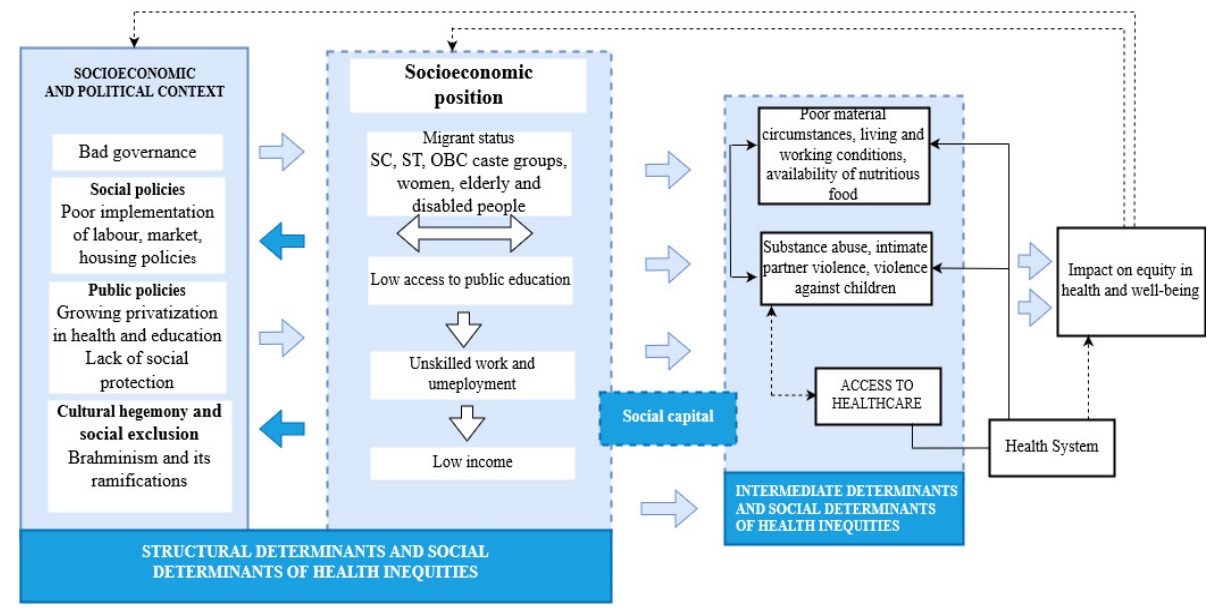

Figure 4: Mapping of Social Capital of study participants on CSDH framework

\section{Conclusion}

This study showed that access to public healthcare services is a challenge for internal migrants in Bilaspur. In this study we used the Commission of Social Determinants of Health framework (2007) and Bourdieu's theory of social capital to conceptualize the role of social capital in access to healthcare. The conceptual and theoretical narrative that has emerged out of this study could be used to further assess the role of social capital in healthcare for marginalized communities. It could help us better understand the role of social capital in achieving equitable healthcare services in Indian settings. There were some limitations of the study, including a small size which makes it difficult to generalize the findings of the study.

A majority of migrants living in Atal Awaas have 'low' social capital. It can be said that 'high' social capital ensues better healthcare access. Traditionally, planning and resource allocation for healthcare are done on the basis of disaggregated data 
(based on gender, age, class, caste, geographic location) but the way in which these identities, social and economic location play out remains unaccounted. Eventually, these factors impact healthcare access of individuals and communities and are left unaccounted. It is important to contextualize the concept of disenfranchisement on a micro-level (power dynamics between local and state governments, hegemonic structures vis-à-vis religion, caste, gender, etc.) and not just on a macro-level (macroeconomic policies, social policies) with an aim to empower local communities. There are glaring gaps in provisioning of public health services, primarily healthcare related services that needs to be addressed with a decentralized approach towards healthcare services that are publicly funded and provided. Improved trust among the people of the community and better social cohesion would also improve healthcare access and utilization but not until the local stakeholders ensure appropriate adequate proper social and political representation of marginalized communities. This would in turn promote a sense of citizenship and facilitate social participation among the community. It is imperative that urban policies are framed and implemented in a manner that migrants are recognized as urban citizens and not just 'migrant workers' who are the backbone of the country's economy. It is critical that migrants have the right to affirm their 'right to city' which includes provisioning of housing, healthcare, social protection (e.g. food security), civil and political rights.

\section{Acknowledgements}

We would like to thank the migrant community living in Atal Awaas for taking time out of their day-to-day lives and allowing us to work with them. We extend our profound gratitude to the community volunteers and respondents of the study for their cooperation and interaction throughout the study.

\section{Declaration of interest}

No potential conflict of interest was reported by the authors.

\section{References}

'A brief profile of Raipur city'. (2000). Shodhganga, November, pp. 67-73. Retrieved from https://shodhganga.inflibnet.ac.in/bitstream/10603/99658/12/12_chapter 3.pdf

Abbas, R., \& Varma, D. (2014). Internal labor migration in India raises integration challenges for migrants. Migration Policy Institute. Retrieved from http://www.migrationpolicy.org/ article/internal-labor-migration-india-raises-integration-challenges-migrants

Alha, A. (2018). The other side of caste as social capital. Social Change, 48(4), pp. 575-588. Retrieved from https://doi.org/10.1177/0049085718801490

Bourdieu, P. (1986). The forms of capital. In Japanese Journal of Human Geography. Issue 4, pp. 241-258. Retrieved from https://doi.org/10.1002/9780470755679.ch15

Census of India. (2011). http://censusindia.gov.in/Ad_Campaign/drop_in_articles/08Migration.pdf

Coleman, J.S. (1988). Social capital in the creation of human capital. American Journal of Sociology, 94, S95-S120. Retrieved from http://www.jstor.org/stable/2780243 
Dodd, W., Humphries, S., Patel, K., Majowicz, S., Little, M., \& Dewey, C. (2017). Determinants of internal migrant health and the healthy migrant effect in South India: a mixed methods study. BMC International Health and Human Rights, 17(1), p. 23. Retrieved from https:// doi.org/10.1186/s12914-017-0132-4

Dye, C., Reeder, J.C., \& Terry, R.F. (2013). Research for universal health coverage. Science Translational Medicine, 5(199). Retrieved from https://doi.org/10.1126/ scitranslmed.3006971

Faetanini, M., Hainry, M., Tewari, S., \& Le Pannerer, J. (2013). Social inclusion of internal migrants in India. Retrieved from http://unesdoc.unesco.org/images/0022/002237/223702e.pdf

Garlick, T., Mary, H., Nicola, D.S., \& Jones, C. (2006). Maternal social capital and child wellbeing in comparative perspective (Issue Paper no. 31).

Gulliford, M., Figueroa-Munoz, J., Morgan, M., Hughes, D., Gibson, B., Beech, R., \& Hudson, M. (2002). What does "access to health care" mean?. Journal of Health Services Research \& Policy, 7(3), pp. 186-188. Retrieved from https://doi.org/10.1258/135581902760082517

Hans, V.B. (2014). Social capital in India: a cause of concern?. SSRN Electronic Journal, pp. 1-16. Retrieved from https://doi.org/10.2139/ssrn.2382399

Ish, M. (2017). Chhattisgarh: nationality movement and the oppressed. Counter Currents. Retrieved from https://countercurrents.org/2017/10/chhattisgarh-nationality-movementand-the-oppressed/

Jasarevic, T. (2019). World Health Assembly Update. Retrieved from https:/www.who.int/ news-room/detail/22-05-2019-world-health-assembly-72-update

Kaplan, A., Hopkins, J., Mullen, P., \& Group, W.B. (2016). Social capital and utilization of health services in Nagaland, India: an exploratory study.

Lone, P.A., \& Rather, N.A. (2012). Internal-migration of Chhattisgarh: socio-economic aspect. IOSR Journal of Business and Management (IOSR-JBM (Vol. 4, Issue 3). www.iosrjournals.org

Ministry of Tribal Affairs. (2014). Tribal profile at a glance (Issue May).

Mosse, D. (2018). Caste and development: Contemporary perspectives on a structure of discrimination and advantage. World Development, 110, pp. 422-436. Retrieved from https://doi.org/10.1016/j.worlddev.2018.06.003

Nandi, S., Dasgupta, R., Garg, S., Sinha, D., Sahu, S., \& Mahobe, R. (2016). Uncovering coverage: utilisation of the universal health insurance scheme, Chhattisgarh by women in slums of Raipur. Indian Journal of Gender Studies, 23(1), pp. 43-68. Retrieved from https://doi.org/10.1177/0971521515612863

Nandi, S., Schneider, H., \& Garg, S. (2018). Assessing geographical inequity in availability of hospital services under the state-funded universal health insurance scheme in Chhattisgarh state, India, using a composite vulnerability index. Global Health Action, 11(1), 1541220. Retrieved from https://doi.org/10.1080/16549716.2018.1541220

Necessities and challenges of reservation in Chhattisgarh. (1999). Shodhganga, pp. 69-112.

Office of Census Commissioner. (2011). Demography of Scheduled Tribes. Government of India., pp. 347-440.

Planning Commission of India. (2011). High level expert group report on universal health coverage for India. Retrieved from https://doi.org/10.1017/CBO9781107415324.004

Rocco, L., \& Suhrcke, M. (2012). Is social capital good for health? A European perspective. In Euro.Who.Int. Retrieved from http://www.euro.who.int/_data/assets/pdf_ file/0005/170078/Is-Social-Capital-good-for-your-health.pdf 
Siisiäinen, M. (2000). Two concepts of social capital: Bourdieu vs. Putnam. ISTR Fourth Internatonal Conference "The Third Sector: For What and for Whom." Retrieved from https://doi.org/10.1083/jcb.200611141

The Movement and Creation of Chhattisgarh. (2000). Shodhganga, pp. 1-126.

Tillin, L. (2014). Statehood without a movement. In Remapping India. Oxford University Press, pp. 109-142. Retrieved from https://doi.org/10.1093/acprof:oso/9780199336036.003.0004

Wilson, I., \& Mccoy, A. (2006). Exploring linkages between maternal social capital and children's nutritional status in Andhra Pradesh.

World Health Organisation European Region. (2015). Intergenerational equity briefing Review of social determinants of health and the health divide in the WHO European Region. Retrieved from http://www.euro.who.int/_data/assets/pdf_file/0005/302873/ Intergenerational-equity-briefing.pdf?ua $=1$

World Health Organization. (2018). Social determinants of health. https://www.who.int/social_ determinants/en/ 